Original Research Paper

\title{
Heavy Metals Pollution of Owerri and Asuokofi Rivers in Konongo, Ghana
}

\author{
${ }^{1 *}$ Wiafe Samuel, ${ }^{2}$ Buamah Richard and ${ }^{3}$ Essandoh Helen \\ ${ }^{1}$ Department of Civil Engineering, Sunyani Technical University, Sunyani-Ghana \\ ${ }^{2,3}$ Department of Civil Engineering, KNUST, Kumasi-Ghana
}

\author{
Article history \\ Received: 16-04-2021 \\ Revised: 22-05-2021 \\ Accepted: 03-06-2021 \\ Corresponding Author: \\ Wiafe Samuel \\ Department of Civil \\ Engineering, Sunyani \\ Technical University, Sunyani- \\ Ghana \\ Email: samwafy@yahoo.co.uk
}

\begin{abstract}
The effects of polluted water and soil resulting from anthropogenic activities have impacted negatively on the livelihood of both human and animal existence. A thorough study was therefore required to ascertain the extent of pollution caused by the undertakings of these anthropogenic activities particularly within the Asante Akim Central Municipality of Ghana. This study assesses the dispersions and the extent of heavy metal pollution within the Owerri and Asuokofi Rivers in the study area. Fourteen water and sediments samples were collected in fourteen locations from the upstream of two Rivers; Owerri and Asuokofi. The samples were collected and poured in clean (sterilised) plastic bottles. A Geographical Positioning System (GPS) "Garmin 62SC" was used to take coordinates for each of the sampled points using WGS 84 as the baseline. Collected samples were digested and analysed for $\mathrm{Hg}, \mathrm{Pb}, \mathrm{As}$ and Cd levels using Inductively Coupled Plasma Mass Spectrometry. The levels of $\mathrm{Pb}, \mathrm{Hg}$, As and $\mathrm{Cd}$ in the water samples were in the ranges of 0.8-9.5, 0.6$3.5,0.02-51$ and $0.2-5.2 \mu \mathrm{g} / \mathrm{L}$ respectively and that of sediments ranged between $7-89,0.06-9.2,10-998$ and $0.1-42 \mathrm{mg} / \mathrm{kg}$ respectively. The results showed that the levels of all the metals in water and sediment samples exceeded the World Health Organization (WHO) recommended levels in water and sediment.
\end{abstract}

Keywords: Heavy Metals, Illegal Mining, Contaminants and Water Quality

\section{Introduction}

Pollution of the environment, particularly water bodies has become a growing concern to governments all over the world (Inyinbor Adejumoke et al., 2018). Various anthropogenic activities such as illegal mining, deforestation, land-use and land cover changes among others are some of the key contributing factors of pollution of water bodies (Khatri and Tyagi, 2015). According to World Health Organisation (WHO) and the United Nation Children's Fund (UNICEF) report (2013), access to improved drinking water sources Haiti has declined in the last 25 year; and the access on-premises to improved water has also decreased from 15 to $7 \%$. About $24 \%$ of the rural populace drinks contaminated water in Ecuador; $21 \%$ of children are stunted and $18 \%$ are underweight (Andres et al., 2018). Bangladesh has Ecoli present in about $80 \%$ of water taps sampled and a similar rate collected from rivers and ponds (Hasan et al., 2019). In Indonesia, only 5\% of urban water is safe to be treated and supplied to consumers (kooy et al., 2018). In
Nigeria, over $60 \%$ of the rural populace live more than 30 min away from a good water source. In Ghana, about $60 \%$ of water bodies are polluted with most of them in critical conditions (Ampomah, 2017).

The pollution of water bodies has caused a devastating impact on the livelihood of various countries and communities around the world. Biodiversity and aquatic ecosystems are affected as a result of the pollution of water. Sometimes the colour of the water is changed with an increase in the mineral content of the water (eutrophication), which adversely impact on the life of the water. The drinking or being in contact with polluted water may result in the contraction of certain diseases such as diarrhea, cholera, typhoid and dysentery or skin infection. According to Fiedler et al., (2019), to attain the Sustainable Development Goals (SDG) on access to safely managed water by the year 2030, countries must spend $\$ 150$ million a year. This is due to the excessive pollution of freshwater bodies.

Mining which is the extraction of minerals from the earth's crust makes a great impact on the landscape, 
environment and the surrounding communities of the earth especially surface mining (Atayi et al., 2016). This involves the clearing of a large area of the forest and agricultural land and these results in serious deforestation and land degradation.

Rapid growth in the mining sector has also attributed to the decrease and degradation of the land, forest cover and the biodiversity, though it serves as a great economic gain for a country economy (Kumar and Pandey, 2013). The mining industry is the second largest industry after agriculture at all scale and regions and it has played a vital role in the development of civilization from ancient times (Lodha et al., 2009). As an example, according to (Seccatore et al., 2014), Ghana's mining sector contributes about $40 \%$ of gross foreign exchange earnings, generates some $5.7 \%$ of GDP. During mining activities, large vegetation is cleared; huge pits dug to obtain the rocks rich in granite and limestone. The continuous extraction of the natural resources leads to the direct loss of the forest due to the frequent damage of the forest land, removal of the fertile topsoil layers (Berihu et al., 2017), thereby resulting in the shortage of fuel woods, grazing area, increase in soil erosion and air pollution. This situation negatively affects people living within the mining areas (Nzunda, 2013).

Surface mining operations in Ghana have become a topical issue due to the devastating effects they are having on the environment. The extent of the devastation is assuming alarming proportions by the day and has destroyed both the environment and natural habitats (Emmanuel et al., 2018). Some of the destructive occurrences instigated by this menace are the destruction of both vegetative and forest covers. Approximately $38 \%$ of the forest reserves in Ghana are depleted by mining activities (Levin, 2004). Excavated pits are left uncovered which results in some of them being stagnated with wastewater thereby breeding both reptiles and insects and serving as a death trap to the populace within these catchments (George, 2013). These defects on the environments give rise to the incidence of the outbreak of epidemic and people being drowned in water stagnated in trenches which are left uncovered. One of the most devious effects this menace has caused the environment is the pollution of water bodies with heavy metals and other contaminants (Bansah et al., 2016). Heavy metal pollution in both water/sediments of rivers as well as soil within the affected catchments poses lots of health threats to both human and animal existence (Lu, 2012; Persaud et al., 2017). In most of these affected catchments, farming is one of their primary source of employment. During the dry season, the farmers usually resort to streams and rivers as their source water for irrigating their farmlands. However, due to the over-exploitation of these water bodies, the farmers are left with no option than to irrigate their farmlands with these polluted water. Consequently, both the soil and farmlands get contaminated by these pollutants and subsequently get ingested by both man and animals, thereby endangering lives (García et al., 2015).

Metallic pollutants generally do not remain at the place of discharge but travel along the flow lines of the receiving rivers (Amankwah, 2013). The general question raising a concern with regards to today's mining activities includes the following: What are the use land-use changes in the atypical mining area, to what extent are these metallic pollutants dispersed in water, what are the levels of pollution these activities are generating, what is the impact on the water quality generally on the receiving rivers. To address these issues, this study was anchored on the following objectives: To ascertain the land cover changes as a result of the activities of small scale mining, to determine the effect of the mining activities on the water quality of the affected water bodies and to ascertain the level of contamination of the river sediments.

\section{Materials and Methods}

\section{Study Area}

The study area forms part of the districts under the jurisdiction of the Asante Region of Ghana (Fig. 1). The area lies within latitude 6030 ' North and $7030^{\prime}$ North and longitude 00 15' West and 10 20' West. It spans over an area of $1,160 \mathrm{Km}^{2}$ with a population of 71,238 (Ghana Statistical Service, 2012). The study commenced from River Agogowa, a river that serves as a distributary to both the Owerri and Asuokofi Rivers. Mining activities are virtually non-existent within the enclave of River Agogowa which also serves as a control, but rather predominant within the catchment of the Owerri and Asuokofi. The area lies in the semi-tropical belt described by two precipitation maxima. The initial rainy season is from May to July and the subsequent from September to November. Mean yearly precipitation runs in the range of 855 and $1,500 \mathrm{~mm}$. The normal stormy days for the year is in the range of 110 and 120 days. The dry harmattan season occurs between December and April and is related to dry conditions, high temperatures and early morning damp/mist and chilly climate conditions. Streams evaporate during this period. Temperature is observed to be consistently high throughout the entire year with a mean yearly temperature of $26^{\circ} \mathrm{C}$. Humidity is high during the stormy season. Their area records extremely lower moisture conditions between December and February, (Boadi et al., 2013). 


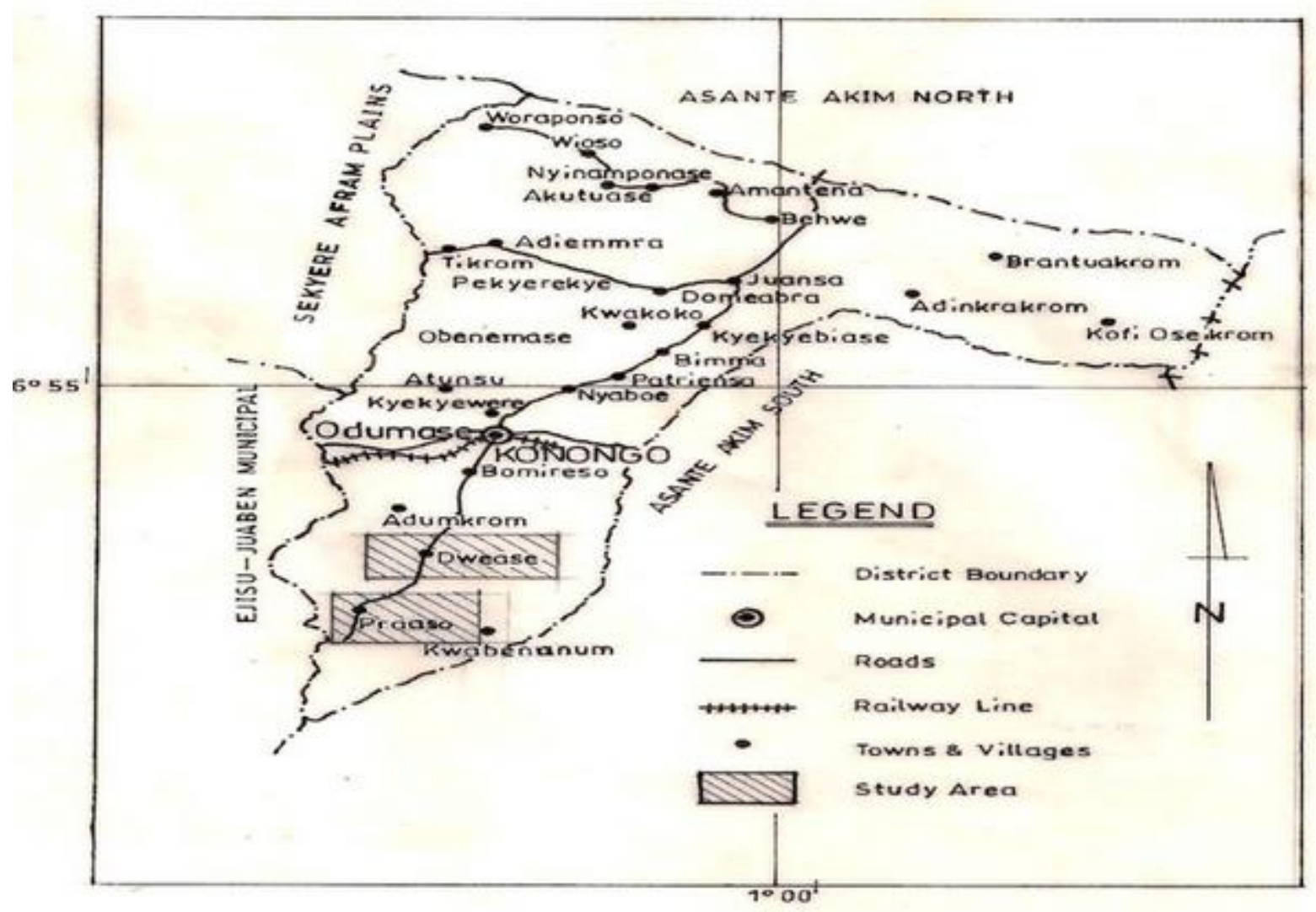

Fig. 1: Map of Asante Akim Central Municipality taken during the 2012 population and housing census in Ghana

\section{Sampling Sites}

The sampling sites were selected based on their strategic locations affected by the activities of small scale mining and its associated impact on water bodies in the area. The fourteen water and sediment samples ( 7 from each River) were identified and collected at locations affected mostly by the mining activities. Water and sediment samples were taken upstream from River Agogowa (Agogo), approximately $35 \mathrm{~km}$ from the study area, which has no record of small scale mining activity were taken and analysed to serve as a control. The sampled sites were given different designations. The aim was to ascertain the causes of the pollutants within the water and sediments of the two Rivers.

\section{Sampling Methodology and Sample Treatment}

The sampling was designed to cover eight months, spanning between March 2017 and November 2017. Fourteen water and sediments samples in fourteen locations from the Two Rivers/streams; Owerri and Asuokofi were collected into clean (sterilised) tetrafluoroethylene (Teflon) containers. The containers were rinsed twice with water from the rivers. At each river/stream sampling points, about $0.25 \mathrm{~L}$ of water were collected from the centre of the river at a depth of $20 \mathrm{~cm}$ below the water surface (Shanbehzadeh et al. 2014). The containers were filled with the samples, leaving approximately $1 \%$ of the volume empty to allow for possible thermal expansion. Sediment samples weighing $250 \mathrm{~g}$ were also scooped using the sediment scoop sampler below the water surface from the centre of the river. The water samples were kept in pre-labelled Tetrafluoroethylene (Teflon) containers which had been rinsed with $10 \% \mathrm{HNO}_{3}$. About $4 \mathrm{~cm}^{3}$ of $\mathrm{HNO}_{3}$ was added to the water samples before capping of the containers that contained the water samples to stabilize the heavy metals. The sediment samples were also collected into pre-labelled, polypropylene transparent bags. The bags were securely tired and placed in another bag, which was then sealed with duct tape. All the samples were stored in an ice chest with ice to maintain a low temperature of $4^{\circ} \mathrm{C}$ and then sent to the Ecological laboratory of the University of Ghana for analysis. A Geographical Positioning System (GPS) "Garmin 62SC" was used to take coordinates for each of the sampled points using WGS 84 as the baseline. Both 
sediment and water samples for each of the sampled locations were taken with all the coordinated points converted into shape files using the geographic coordinate system. Geographic bound was considered to limit on the extent of the geographic area mapped but not the entire Municipality. For the digestion of the water samples, $20 \mathrm{~mL}$ of water samples were mixed with $5 \mathrm{~mL}$ of nitric acid and $2 \mathrm{~mL}$ hydrogen peroxide. The sediment samples were dried in an oven at $105^{\circ} \mathrm{C}$ for $24 \mathrm{~h}$. The dried samples were powdered using an agate mortar and pestle to achieve a homogeneous mixture and then were passed through a 63 -micron sieve. Thereafter, $1 \mathrm{~g}$ of the sediments was digested by adding a mixture of nitric acid and concentrated per chloric acid with a ratio of $4: 1$ through exposure to $40^{\circ} \mathrm{C}$ for $1 \mathrm{~h}$ and $140^{\circ} \mathrm{C}$ for $4 \mathrm{~h}$. The total metal content of water and sediment samples was performed by Inductively Coupled Plasma Mass Spectrometry. Changes in Land Use Land Cover (LULC) maps of 1999, 2009 and 2017 were obtained by extracting shape files from Asante Akim Municipality.

\section{Quality Control}

Duplicate samples were taken, digested and analysed the same way as the samples. All the instruments used in the measurement were well-calibrated to minimise any measurement uncertainty by ensuring the accuracy of test equipment. Digestion Blank approach was employed to assess for possible contamination introduced during sample preparation activities.

\section{Results}

The land use classification in the Asante Akim Central is based on the forest/open forest, settlement/bare land and grass/farmland. Figure 2 shows the land cover classification of the study area in the year 1999 when the menace of illegal mining was virtually non-existent. The area was practically covered by forest/open forest as well as grass/farmland with fewer settlements clustered around the Owerri River ostensibly serving as their major source of water. After ten years (2009), the dynamics of the land use classification changed significantly. The forest/open forest cover and grass/farmlands started depleting with increase in settlement (Fig. 3). This is the period that license were given to small scale miners to mine at the enclave. Due to unemployment in the area, majority of the youth were engaged by the operators of these small scale mining. In 2017, a lot of illegal mining (galamsay) activities had literally engulfed the entire municipality and practically depleting the forest and grass/farmland cover with corresponding increase in the settlement (Fig. 4). Majority of the illegal mining activities were the alluvial method. This method of mining has the propensity of heavily polluting the soil and water bodies with harmful metals like $\mathrm{Hg}, \mathrm{As}, \mathrm{Pb}$ and $\mathrm{Cd}$.

The forest, grassland/farmland and settlements had an estimated land cover of 59.9, 36.9 and $3.2 \%$ respectively (Table 1). These statistics give credence to the fact that the land use of the area has not been static but rather drifted from being a forest belt to grassland/farmland and settlements. These changes in land use might be necessitated by the community's over-reliance on farming as their essential source of income.

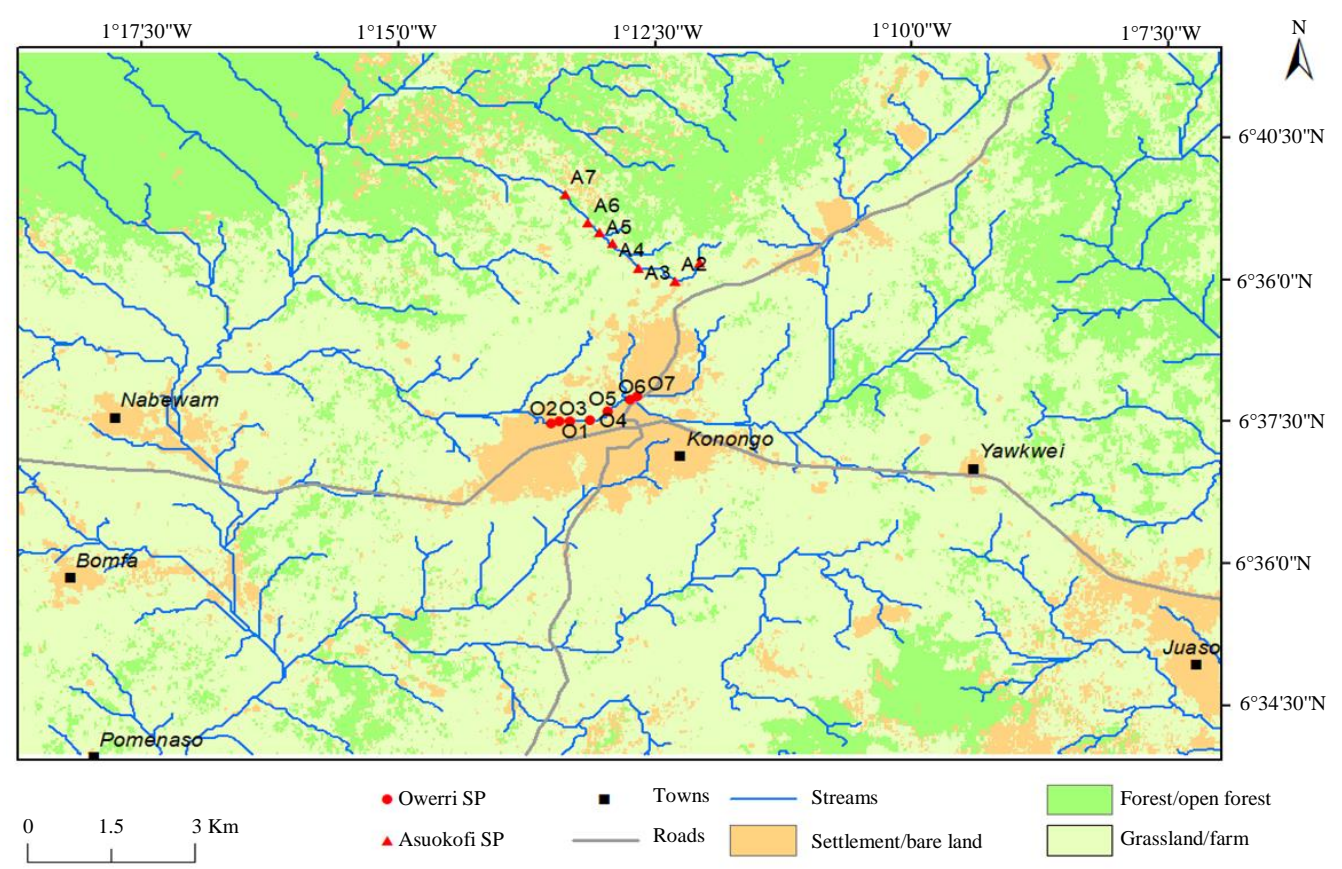

Fig. 2: Land use land cover classification for 1999 in Asante Akim central 


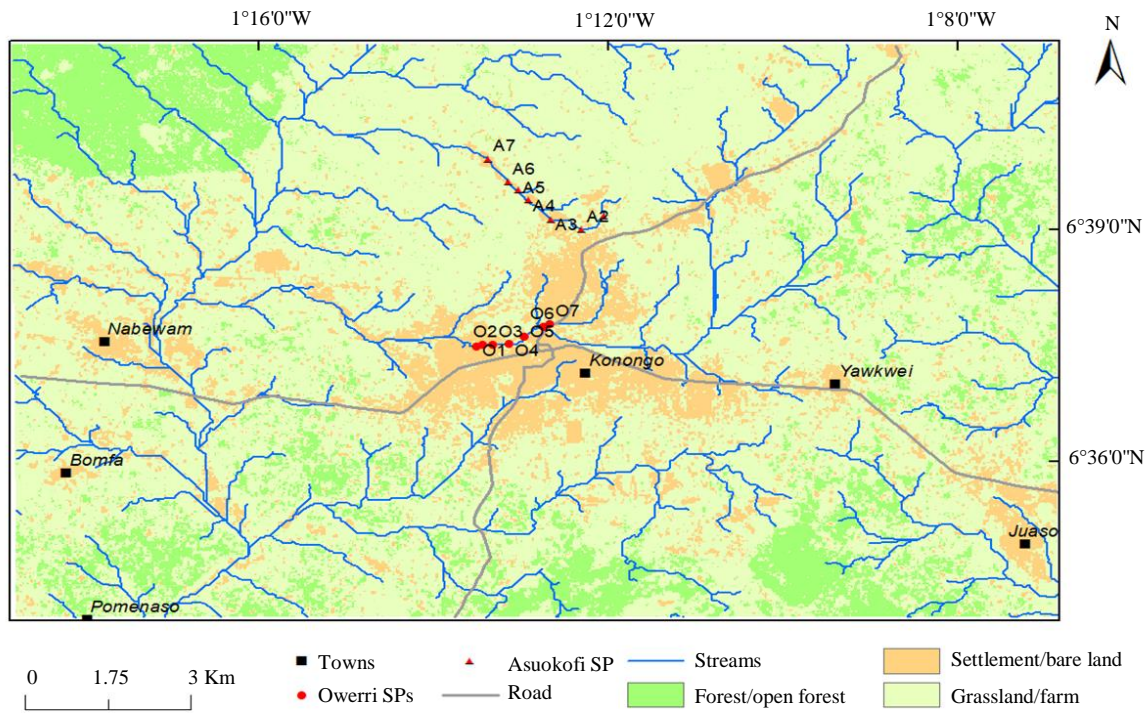

Fig. 3: Land use land cover classification for 2009 in Asante Akim central

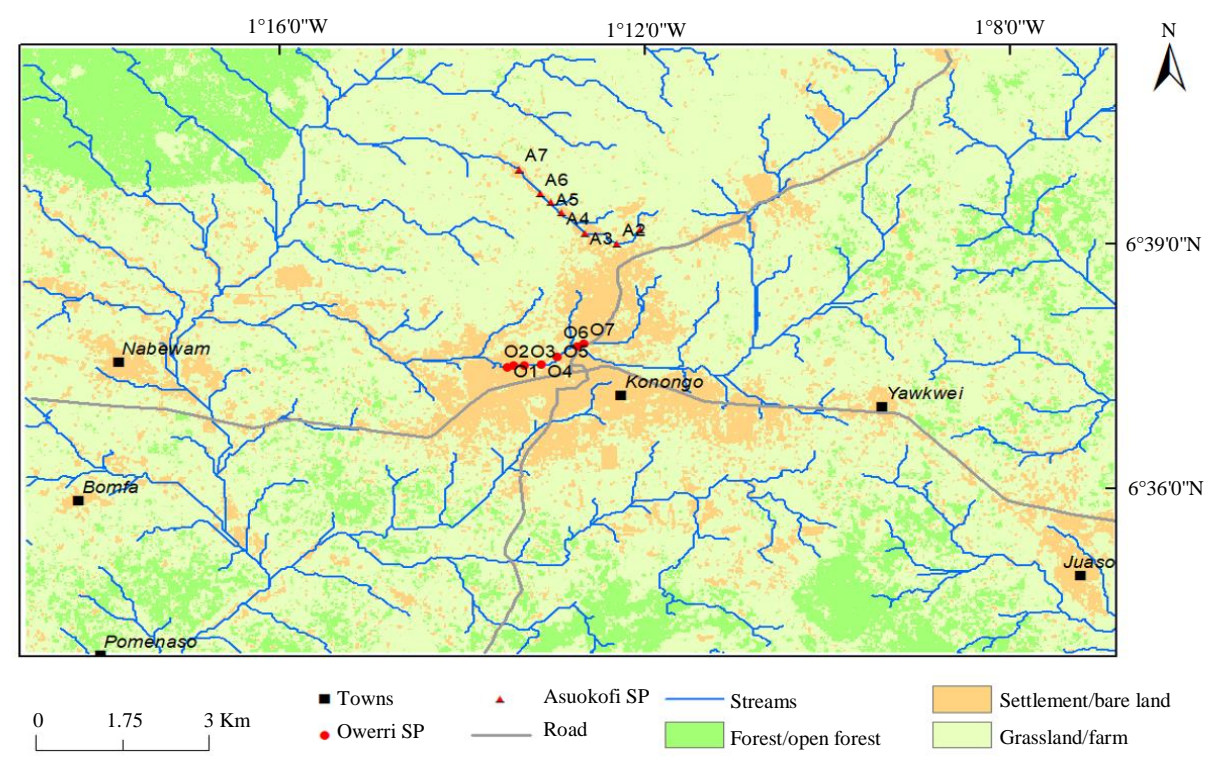

Fig. 4: Land use land cover classification for 2017 in Asante Akim central

Table 1: Land use/land cover changes in the Asante Akim central

\begin{tabular}{|c|c|c|c|c|c|c|}
\hline \multirow[b]{2}{*}{ Classification } & \multicolumn{6}{|c|}{ Years of coverage with percentages } \\
\hline & $1999\left(\mathrm{Km}^{2}\right)$ & $\%$ & $2009\left(\mathrm{Km}^{2}\right)$ & $\%$ & $2017\left(\mathrm{Km}^{2}\right)$ & $\%$ \\
\hline Forest & 180.1 & 59.9 & 81.2 & 26.9 & 45.4 & 15.1 \\
\hline Grass/Farmland & 110.8 & 36.9 & 189.4 & 63.0 & 180.9 & 60.2 \\
\hline Settlement & 9.7 & 3.2 & 30.1 & 10.0 & 74.4 & 24.7 \\
\hline Total & 300.6 & 100.0 & 300.6 & 100.0 & 300.6 & 100.0 \\
\hline
\end{tabular}

According to Ghana's 2010 Population and Housing Census for the Asante Akim Central Municipality, the Agriculture, forestry and fishing industries employed the most significant number of the populace above the age of 15 years $(33.6 \%)$. This was followed by wholesale and retail; repair of motor vehicles and motorcycles $(20.8 \%)$. These two industries accounted for a little over half (54.4\%) of the persons employed. This was expected as workers in the 
informal sector dominate the municipality. Other significant industries include manufacturing (10.1\%), accommodation and food services $(6.1 \%)$, education $(5.6 \%)$ and mining and quarrying $(4.7 \%)$.

The forest cover within the area depleted from 59.9 in 1999 to $26.9 \%$ in 2009 and then finally to $15.09 \%$ in 2017 (Table 1). Concurrently, the settlement cover increased from $3.2 \%$ in $1999,30.06 \%$ in 2009 then finally to $24.7 \%$ in 2017. The total number of households in the Asante Akim Central Municipality according to the 2010 Population and Housing Census is 16,920 . Out of this number, 8,467 (about 50\%) of these households are engaged in agriculture. The farmland cover kept increasing over the period. The dominant agricultural activity is crop farming, which has a proportion of almost ninety-six per cent (95.7\%). This is followed by livestock rearing (20.8\%) with tree planting and fish farming constituting less than one per cent $(0.6 \%)$. This trend is just the same for rural households in both urban and rural localities. These statistics give ample attestation of the community's reliance on the available water resources for their livelihood. The two significant sources of water in the community are the Owerri and Asuokofi Rivers from which the citizenry depends largely on for drinking, irrigation of farmlands and other purposes. Unfortunately, the activities of Small-scale mining in the Asante Akim Municipality became prevalent between the years 2008-2016 (George, 2013) and it was largely dominated within the enclave of the Owerri and Asuokofi Rivers. The activities of the illegal miners in no doubt polluted these Rivers and consequently became a threat to both humans and livestock.

Apart from the activities of illegal mining, there are other activities such as an auto mechanic workshop, farming and market along the banks of the Two Rivers.

\section{Levels of Heavy Metals in Owerri and Asuokofi Rivers}

Figure 5-8 shows the levels of the heavy metals in the water samples of the Owerri and Asuokofi Rivers. The illegal mining activities were sited along both Rivers at locations (Points) 1, 2 and 3 within the study area (Ashante Akim Central).

\section{Levels of Lead and Mercury in the Owerri and Asuokofi Rivers}

The levels of $\mathrm{Pb}$ at each of the sampled points in the Asuokofi River were all above the levels at the control location (Fig. 5). The levels of $\mathrm{Pb}$ was high at sampled locations 1 and 2 and declined afterwards along the flow lines all through to sampled location 7. Except for sampled locations 6 and 7 in the Owerri River, all the other points sampled had the $\mathrm{Pb}$ levels above that at the control location. Location 1 of Owerri recorded the highest levels of $\mathrm{Pb}$ and consequently declined drastically to location 2 . There was a marginal increase in the levels of $\mathrm{Pb}$ from location 2 to 3 in the Owerri River but subsequently declined after location 3 through to location 7 . The occurrence of $\mathrm{Pb}$ prevalently at tested areas 1,2 and 3 might be ascribed to the draining of leaded gas from a portion of the hardware excavators, mechanized plants or trommels utilized by the diggers just as the exercises of the automobile shop situated at the mining locales apparently to fix the gear of the excavators. When the $\mathrm{Pb}$ was leached into the Rivers at these points, they were expected to flow along the flow lines downstream, however, there were decreasing levels of $\mathrm{Pb}$ downstream and this could be as a result of the possible settling of $\mathrm{Pb}$ at the sediments of the River.

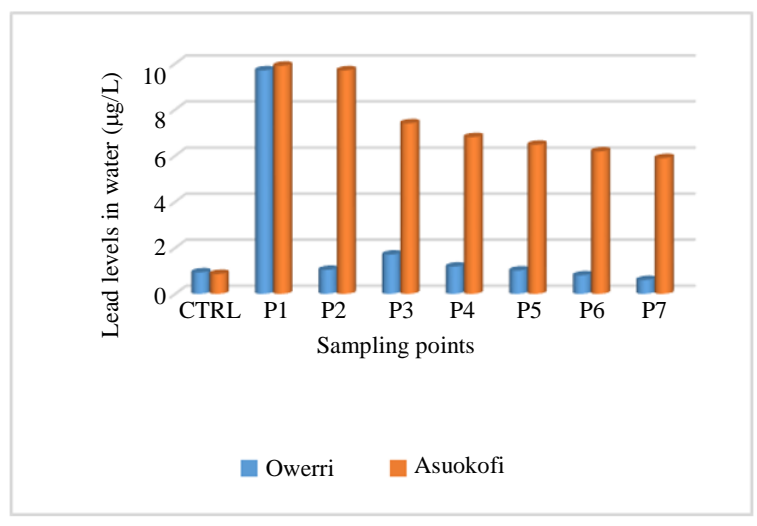

Fig. 5: Dispersion of $\mathrm{Pb}$ within Owerri and Asuokofi streams

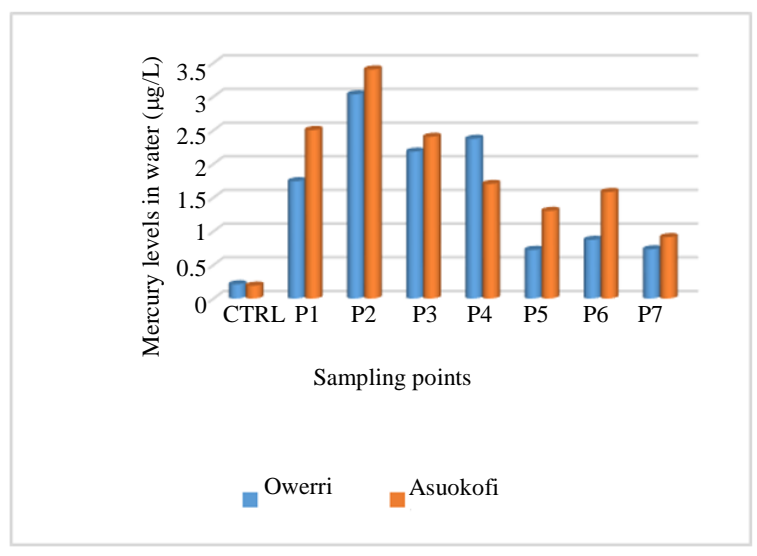

Fig. 6: Dispersion of Hg within Owerri and Asuokofi streams 
The levels of $\mathrm{Hg}$ in both Owerri and Asuokofi Rivers were all above the levels recorded in the controlled sample. There was a gradual increase in the levels of $\mathrm{Hg}$ from location 1 to location 2 within the two Rivers, consequently, the levels of $\mathrm{Hg}$ declined steadily from location 2 through to location 7. Before long, $\mathrm{Hg}$ is used to removing gold from mineral as an amalgam. The amalgamation is usually separated by hand and thereafter warmed to refine the $\mathrm{Hg}$ and segregate the gold. The technique of amalgamation is reiterated three times to enhance the removal of the gold. This may account for the high levels of $\mathrm{Hg}$ at sampled points 1, 2 and 3 which incidentally happens to be where the activity of illegal gold mining was prevalent. Mercury is stable and does not easily dissolve in water but will float on the surface or form alloys in most metals and they can only dissolve in fats and oils. The $\mathrm{Hg}$ was likely collected together with the River water by the inhabitants to either irrigate their farmlands or used for other domestics purposes at some points along with the flow of the River. The levels of $\mathrm{Hg}$ at other locations where the activity of illegal mining was not prevalent (4, 56 and 7) along the flow lines were not considerably lower than the locations where the activities were prevalent. This may be attributed to the inability of $\mathrm{Hg}$ to easily dissolve in water at normal temperatures.

The mean and standard deviation of the physicochemical parameters of the two rivers are indicated in Table 2. The mean levels of $\mathrm{Pb}$ and $\mathrm{Cd}$ in the rivers are $5.33 \pm 0.4$ and $1.78 \pm 0.1$ respectively which are lower than the WHO standards of 10 and $5.0 \mu \mathrm{g} / \mathrm{L}$ respectively. The mean levels of $\mathrm{Hg}$ and As are respectively $1.27 \pm 0.2$ and $12.83 \pm 0.7$, higher than the WHO standard values of 1.0 and $10 \mu \mathrm{g} / \mathrm{L}$ respectively. The level of $\mathrm{pH}$ in the rivers $(6.30 \pm 0.1)$ was within the WHO standard of 6.5-8.5. Conductivity, TDS and Turbidity values were $159.60 \pm 1.7,107.23 \pm 1.0$ and $4128 \pm 3.1$ respectively. With the exception of TDS, levels of Conductivity and Turbidity are above the WHO standards of $5 \mathrm{NTU}$ and $500 \mu \mathrm{s} / \mathrm{cm}$.

\section{Levels of Arsenic and Cadmium in the Owerri and Asuokofi Rivers}

The dispersion of As within the Owerri River was virtually non-existent, on the other hand, As recorded the highest levels at location 1 and further declined along the flow lines to location 7 in the Asuokofi River. The levels of As within the Asuokofi River were high at locations 3-5, indicating high pollution within those catchments (Fig. 7). Arsenic occurs normally in rocks and soil, water, air, plants. Volcanic movement, the disintegration of rocks and minerals and backwoods flames are common sources that can discharge As into the environment. Adsorption of As to fine particles in water and precipitation with aluminium or iron hydroxides makes As enter develop. After some time arsenic may isolate a little while later significant to decrease responses. Arsenic blends may expeditiously separate in the water and in this way their dynamic lessens in their levels along the streamlines of the Asuokofi River.

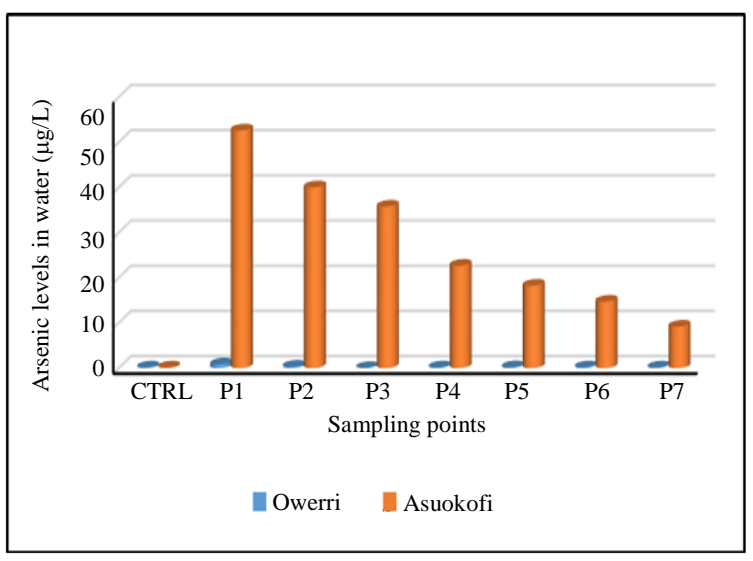

Fig. 7: Dispersion of As within Owerri and Asuokofi streams

Table 2: Levels of contaminants in the two rivers

\begin{tabular}{|c|c|c|c|c|}
\hline Dependent variables & Sample type & $\mathrm{N}$ & Mean \pm SD & WHO Standard \\
\hline \multirow[t]{2}{*}{$\overline{\operatorname{Lead}(\mathrm{Pb})}$} & Sediments (mg/kg) & 30 & $32.14 \pm 28.26$ & $35.8 \mathrm{mg} / \mathrm{kg}$ \\
\hline & Water $(\mu \mathrm{g} / \mathrm{L})$ & 30 & $5.33 \pm 4.01$ & $10 \mu \mathrm{g} / \mathrm{L}$ \\
\hline \multirow[t]{2}{*}{$\operatorname{Mercury}(\mathrm{Hg})$} & Sediments (mg/kg) & 30 & $1.57 \pm 1.34$ & $0.18 \mathrm{mg} / \mathrm{kg}$ \\
\hline & Water $(\mu \mathrm{g} / \mathrm{L})$ & 30 & $1.27 \pm 1.72$ & $1.0 \mu \mathrm{g} / \mathrm{L}$ \\
\hline \multirow[t]{2}{*}{ Arsenic(As) } & Sediments (mg/kg) & 30 & $256.88 \pm 49.45$ & $9.79 \mathrm{mg} / \mathrm{kg}$ \\
\hline & Water $(\mu \mathrm{g} / \mathrm{L})$ & 30 & $12.83 \pm 20.07$ & $10 \mu \mathrm{g} / \mathrm{L}$ \\
\hline \multirow[t]{2}{*}{ Cadmium $(\mathrm{Cd})$} & Sediments (mg/kg) & 30 & $1.70 \pm 1.49$ & $0.99 \mathrm{mg} / \mathrm{kg}$ \\
\hline & Water $(\mu \mathrm{g} / \mathrm{L})$ & 30 & $1.78 \pm 1.96$ & $5.0 \mu \mathrm{g} / \mathrm{L}$ \\
\hline \multirow[t]{2}{*}{$\mathrm{pH}$} & Sediments (mg/kg) & - & - & \\
\hline & Water $(\mu \mathrm{g} / \mathrm{L})$ & 30 & $6.30 \pm 1.15$ & $6.5-8.5$ \\
\hline \multirow[t]{2}{*}{ Conductivity $(\mu \mathrm{S} / \mathrm{cm})$} & Sediments (mg/kg) & - & - & \\
\hline & Water $(\mu \mathrm{g} / \mathrm{L})$ & 30 & $159.60 \pm 14.77$ & $5 \mathrm{NTU}$ \\
\hline \multirow{2}{*}{$\mathrm{TDS}(\mathrm{mg} / \mathrm{l})$} & Sediments (mg/kg) & - & - & \\
\hline & Water $(\mu \mathrm{g} / \mathrm{L})$ & 30 & $107.23 \pm 30.05$ & $259-500 \mathrm{mg} / \mathrm{L}$ \\
\hline \multirow[t]{2}{*}{ Turbidity(NTU) } & Sediments (mg/kg) & - & - & \\
\hline & Water $(\mu \mathrm{g} / \mathrm{L})$ & 30 & $4128 \pm 843$ & $500 \mu \mathrm{S} / \mathrm{cm}$ \\
\hline
\end{tabular}


The levels of Cd within Owerri River were well dispersed along the flow lines at locations 2 and 3 with the highest levels of $\mathrm{Cd}$ (Fig. 8). However, the levels within the Asuokofi were minimal and were dispersed along the flow lines (Fig. 8). Cadmium, an uncommon yet broadly scattered component, is found normally in nature. It is discharged into nature through mining and purifying. The presence of $\mathrm{Cd}$ particularly in the Owerri River could be as a result of the activities of intense mining within the affected catchment (Fig. 8).

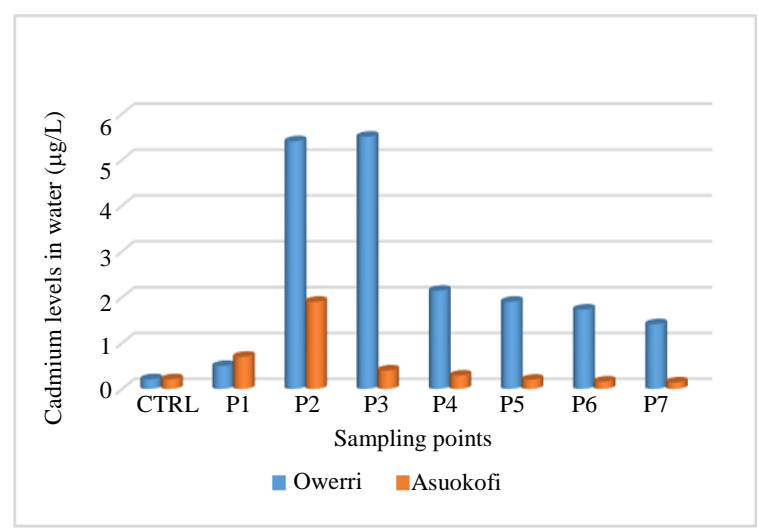

Fig. 8: Dispersion of Cd within Owerri and Asuokofi streams

\section{Levels of Heavy Metals in the Sediments of Owerri and Asuokofi Rivers}

Figure 9-12 shows the levels of $\mathrm{Pb}, \mathrm{Hg}, \mathrm{As}$ and $\mathrm{Cd}$ in the sediments of both the Owerri and Asuokofi Rivers.

\section{Levels of Lead and Mercury in the Sediments of Owerri and Asuokofi Rivers}

The levels of $\mathrm{Pb}$ in the sediments of Owerri River were well dispersed and much higher than those within the Asuokofi River. The levels of $\mathrm{Pb}$ at the sampled points 17 in the Owerri River were all higher than that at the source (control), indicating the influence of the illicit mining undertakings within the affected catchments (Fig. 9). Except for sampled points 6 and 7, the levels of $\mathrm{Pb}$ in the sediments of Asuokofi were all above that at the control. Conversely, the levels of $\mathrm{Pb}$ in the stream (water) of Asuokofi and Owerri were all below that of the sediments. The average depth of flow in both Rivers was about $0.8 \mathrm{~m}$ so there is the likelihood of $\mathrm{Pb}$ easily settling and dissolving in the sediments of the Rivers (Duncan et al., 2018). The remediation of $\mathrm{Pb}$ by macrophytes will be much easier with higher levels in the sediments than the water. Therefore the remediation of $\mathrm{Pb}$ in the two Rivers will not take much time.

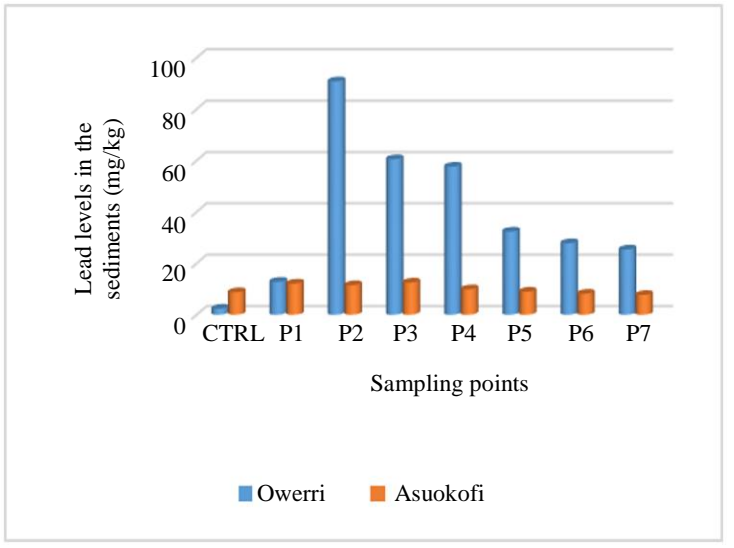

Fig. 9: Dispersion of $\mathrm{Pb}$ within sediments

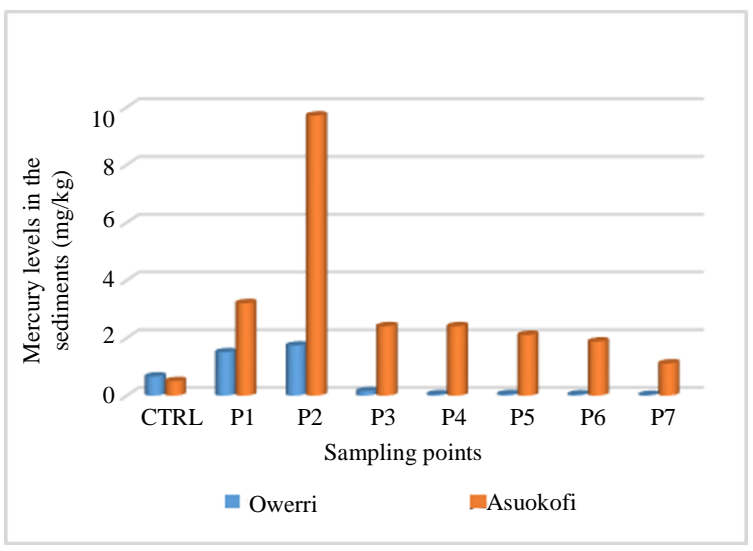

Fig. 10: Dispersion of $\mathrm{Hg}$ within sediments

The levels of $\mathrm{Hg}$ in the sediments of Asuokofi were well dispersed and much higher than those within the Owerri River. The levels of $\mathrm{Hg}$ in the sediments of Asuokofi were above the levels in the water samples of the same River (Fig. 10). This could be the high deposition rate of $\mathrm{Hg}$ at the sediments resulting from the inability of the $\mathrm{Hg}$ to dissolve in the water. However, this argument cannot be held for Owerri as the levels in the water samples were above that of the sediments. Mercury may have formed alloys with other metals in the Owerri River that could have led to the lower levels of $\mathrm{Hg}$ in the sediments of Owerri than the water samples.

\section{Levels of Arsenic and Cadmium in the Sediments of Owerri and Asuokofi Rivers}

The levels of As in the sediments of Asuokofi were very minimal and almost at the same levels with the source location. On the contrary, the levels of As in the sediments of Owerri were high at sampled locations. In other words, the 
levels of As in the sediments of Owerri were higher than that of the Asuokofi River. The levels of As in the water samples of Owerri were much lower than that within the sediments of the same River. This is an indication of the fact that almost all the As metal settled at the sediments of the Owerri River, there is the tendency of the As metal to easily dissolve into the stream (water) at the slightest of subsidence of movement of the ground within that enclave. Particular attention must be given to the remediation of As in the Owerri River in all sampled locations.

The levels of $\mathrm{Cd}$ in the sediments of Asuokofi were well dispersed along the flow lines (Fig. 12). Except sampled point 2 which recorded the highest levels of $\mathrm{Cd}$, the levels of $\mathrm{Cd}$ in the sediment of the rest of the sampled points were low.

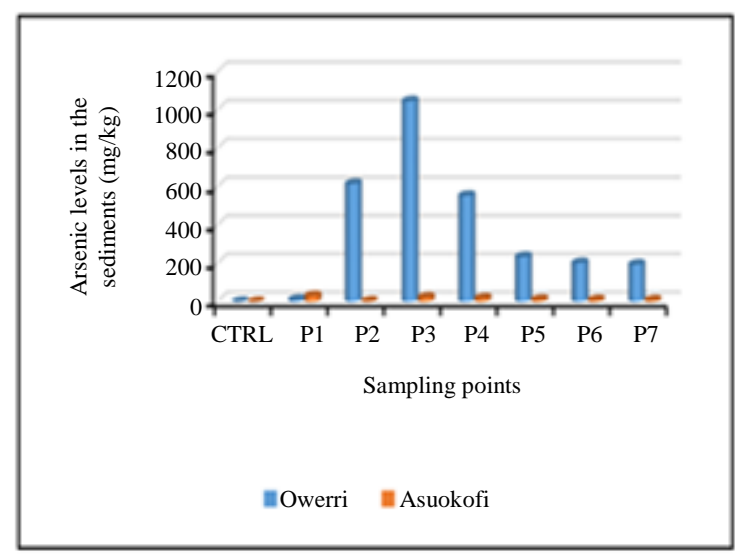

Fig. 11: Dispersion of Arsenic within sediments

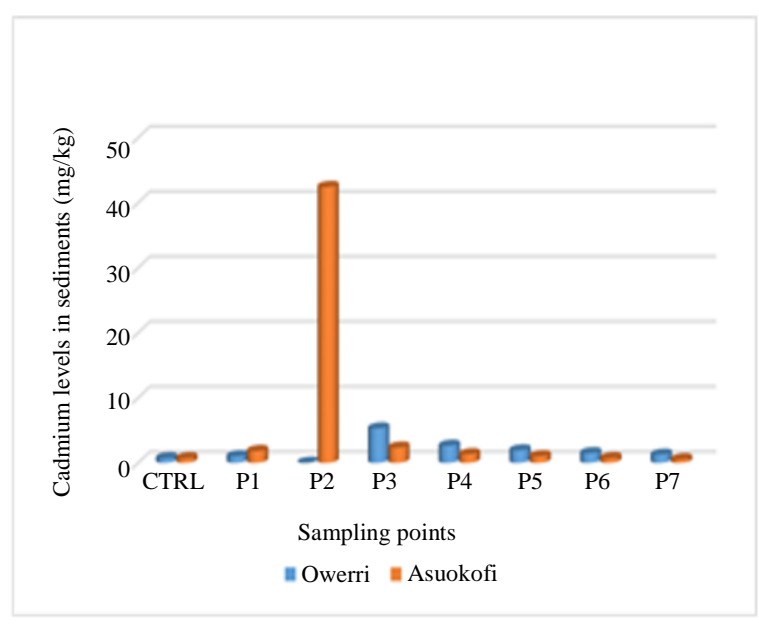

Fig 12: Dispersion of Cadmium within sediments

There is a positive correlation between $\mathrm{Pb}$ and $\mathrm{As}(0.88)$ (Table 3). The higher the levels of $\mathrm{Pb}$ in the stream, the higher the corresponding levels of As. The level of correlation between $\mathrm{Pb}$ and $\mathrm{As}$ is statistically significant $(\mathrm{t}$ value $=0.00$ ). This is an indication that there would be more than $95 \%$ chance to see both pollutants moving in the same direction. The correlation between $\mathrm{Pb}$ and $\mathrm{Cd}$ is negative (-0.04). The increase in the levels of $\mathrm{Pb}$ in the river would be associated with the decrease in the levels of $\mathrm{Cd}$ and vice versa. However, the negative correlation between $\mathrm{Pb}$ and $\mathrm{Cd}$ is not statistically significant $(\mathrm{T}$-value $=0.77)$. The correlation between $\mathrm{Pb}$ and $\mathrm{pH}$ is positive $(0.465)$. The rise in the level of $\mathrm{Pb}$ might see a corresponding rise in the $\mathrm{pH}$ level of the water. The correlation between $\mathrm{Pb}$ and $\mathrm{pH}$ is statistically significant $(\mathrm{T}$-value $=0.01)$. The rise in the level of $\mathrm{Pb}$ in water would cause the $\mathrm{pH}$ level to also rise. There is a negative correlation between $\mathrm{Pb}$ and conductivity as well as TDS (-0.89 and -0.33 respectively). The rise in levels of Conductivity, TDS and Turbidity might cause a decrease in the levels of $\mathrm{Pb}$ in water. However, the negative correlation between $\mathrm{Pb}$ and conductivity, TDS as well turbidity is not statistically significant $(0.64,0.08$ and 0.49 respectively). This means that there wouldn't be any basis to predict an increase in Conductivity, TDS and Turbidity with a decrease in $\mathrm{Pb}$.

The correlation between $\mathrm{Hg}$ and $\mathrm{Cd}$ as well as As are negatively correlated $(\mathrm{Hg} r \mathrm{Cd}=-0.33$ and $\mathrm{Hg} r$ As $=-0.36)$. Statistically, the correlation between $\mathrm{Hg}$ and $\mathrm{Cd}$ as well as between $\mathrm{Hg}$ and $\mathrm{As}$ are significant. An increase of $\mathrm{Hg}$ in water may cause a corresponding decrease of $\mathrm{Cd}$ and As. There is a 95\% chance of lower levels of Cd with the increase in $\mathrm{Hg}$ levels in the water. There stand a $99 \%$ chance seeing higher levels of $\mathrm{Hg}$ with corresponding decrease levels of As in water. $\mathrm{Hg}$ has a positive correlation with $\mathrm{pH}(0.42)$ and the level of correlation between $\mathrm{Hg}$ and $\mathrm{pH}$ is not statistically significant. Conductivity and turbidity have a positive correlation with $\mathrm{Hg}(\mathrm{Hg} \mathrm{r}$ conductivity = $0.002, \mathrm{Hg} r$ turbidity $=0.31$ ), however, the correlation between $\mathrm{Hg}$ and Conductivity as well as turbidity are not statistically significant. $\mathrm{Hg}$ has a negative correlation with TDS (-0.48) and the levels of correlation between them are statistically significant $(\mathrm{t}=0.007)$. This means an increase in the levels of $\mathrm{Hg}$ might see a decrease in the levels of TDS.

There is a positive correlation between As and $\mathrm{Cd}$ (0.26) and the level of correlation is statistically significant (Table 3). The levels of As and Cd moves in the same direction in the water. The correlation between As and $\mathrm{pH}$ together with turbidity are positively correlated and the levels of correlation between them are statistically significant. Thus, the higher the levels of As in the water, the higher the $\mathrm{pH}$ and turbidity levels respectively. The correlation between As and TDS is negatively correlated (-0.05) and the level of correlation is not statistically significant $(t=0.79)$. 
Table 3: Correlation analysis between measured samples

\begin{tabular}{|c|c|c|c|c|c|c|c|c|c|c|}
\hline Variables & Statistics & $\begin{array}{l}\text { Lead } \\
(\mathrm{Pb})\end{array}$ & $\begin{array}{l}\text { Mercury } \\
(\mathrm{Hg})\end{array}$ & $\begin{array}{l}\text { Arsenic } \\
\text { (As) }\end{array}$ & $\begin{array}{l}\text { Cadmium } \\
\text { (Cd) }\end{array}$ & $\mathrm{pH}$ & $\begin{array}{l}\text { Conductivity } \\
(\mu \mathrm{S} / \mathrm{cm})\end{array}$ & $\begin{array}{l}\text { TDS } \\
(\mathrm{mg} / \mathrm{l})\end{array}$ & $\begin{array}{l}\text { Turbidity } \\
\text { (NTU) }\end{array}$ & $\begin{array}{l}\text { Colour } \\
(\mathrm{Pt} / \mathrm{Co})\end{array}$ \\
\hline \multirow[t]{2}{*}{ Lead $(\mathrm{Pb})$} & Correlation & 1 & $-0.30^{*}$ & $0.88^{* *}$ & -0.04 & $0.46^{*}$ & -0.09 & -0.32 & 0.13 & 0.29 \\
\hline & Sig. (2-tailed) & & 0.02 & 0.00 & 0.77 & 0.01 & 0.64 & 0.08 & 0.49 & 0.19 \\
\hline \multirow[t]{2}{*}{ Mercury $(\mathrm{Hg})$} & Correlation & $-0.30^{*}$ & 1 & $-0.36^{* *}$ & $-0.33^{*}$ & $0.42^{*}$ & 0.00 & $-0.48^{* *}$ & .31 & $0.59^{* * *}$ \\
\hline & Sig. (2-tailed) & 0.02 & & 0.01 & 0.01 & 0.02 & 0.99 & 0.01 & 0.09 & 0.00 \\
\hline \multirow{2}{*}{ Arsenic (As) } & Correlation & $0.88^{* *}$ & $-0.36^{* *}$ & 1 & $0.26^{*}$ & $0.47^{* *}$ & 0.30 & -0.05 & $0.65^{* *}$ & $0.79^{* *}$ \\
\hline & Sig. (2-tailed) & 0.00 & 0.01 & & 0.04 & 0.01 & 0.10 & 0.79 & 0.00 & 0.00 \\
\hline \multirow{2}{*}{ Cadmium (Cd) } & Correlation & -0.04 & $-0.33^{*}$ & $0.26^{*}$ & 1 & $-0.54^{* *}$ & 0.09 & -0.05 & -0.17 & -0.33 \\
\hline & Sig. (2-tailed) & 0.77 & 0.01 & 0.04 & & 0.00 & 0.63 & 0.81 & 0.36 & .075 \\
\hline \multirow[t]{2}{*}{$\mathrm{pH}$} & Correlation & $0.46^{*}$ & $0.42^{*}$ & $0.47^{* *}$ & $-0.54^{* *}$ & 1 & $0.53^{* *}$ & -0.20 & 0.09 & 0.19 \\
\hline & Sig. (2-tailed) & 0.01 & 0.02 & 0.01 & 0.00 & & 0.00 & 0.278 & 0.64 & 0.32 \\
\hline \multirow{4}{*}{$\begin{array}{l}\text { Conductivity } \\
(\mu \mathrm{S} / \mathrm{cm}) \\
\text { TDS }(\mathrm{mg} / \mathrm{l})\end{array}$} & Correlation & -0.09 & 0.00 & 0.30 & 0.09 & $0.53^{* *}$ & 1 & 0.29 & $0.45^{*}$ & 0.22 \\
\hline & Sig. (2-tailed) & 0.64 & 0.99 & 0.10 & 0.63 & 0.00 & & 0.12 & 0.01 & 0.24 \\
\hline & Correlation & -0.32 & $-0.48^{* *}$ & -0.05 & -0.05 & -0.20 & 0.29 & 1 & $0.40^{*}$ & 0.06 \\
\hline & Sig. (2-tailed) & 0.08 & 0.01 & 0.79 & 0.81 & 0.28 & 0.12 & & 0.03 & 0.77 \\
\hline \multirow[t]{2}{*}{ Turbidity (NTU) } & Correlation & 0.13 & 0.31 & $0.65^{* *}$ & -0.17 & 0.09 & $0.45^{*}$ & $0.40^{*}$ & 1 & $0.84^{* *}$ \\
\hline & Sig. (2-tailed) & 0.49 & 0.09 & 0.00 & 0.36 & 0.64 & 0.01 & 0.03 & & 0.00 \\
\hline \multirow[t]{2}{*}{ Colour $(\mathrm{Pt} / \mathrm{Co})$} & Correlation & 0.29 & $0.59^{* *}$ & $0.79^{* *}$ & -0.33 & 0.19 & 0.22 & 0.06 & $0.84^{* *}$ & 1 \\
\hline & Sig. (2-tailed) & 0.13 & 0.00 & 0.00 & 0.08 & 0.32 & 0.24 & 0.77 & 0.00 & \\
\hline
\end{tabular}

*. Correlation is significant at the 0.05 level (2-tailed)

**. Correlation is significant at the 0.01 level (2-tailed)

The correlation between $\mathrm{Cd}$ and $\mathrm{pH}$ is negatively correlated (-0.54) and the level of correlation is significant $(\mathrm{T}=0.00)$. Conductivity has a positive correlation with $\mathrm{Cd}$ (0.09), however, the level of correlation between conductivity and $\mathrm{Cd}$ is not statistically significant. There is a negative correlation between $\mathrm{Cd}$ and TDS as well as turbidity $(\mathrm{Cd} r$ TDS $=-0.049, \mathrm{Cd} r$ turbidity $=0.17)$. However, the level of correlation between Cd and TDS as well as turbidity is not statistically significant. This is to say, the levels of TDS has no bearing on the levels of $\mathrm{Cd}$.

\section{Discussion}

The results obtained indicated the contamination of the Two Rivers; Asuokofi and Owerri in the study area as a result of the activities of illegal mining. All the four heavy metals identified; $\mathrm{Hg}, \mathrm{As}, \mathrm{Pb}$ and $\mathrm{Cd}$ were all found to be in elevated levels within the two Rivers (Table 2). The levels of the heavy metals at the source (control) of both Rivers were lower than that at locations 1-5. There was no activity of illegal mining at the source of the streams and hence this observation validates the assertion that the activity of illegal mining could be part of the main causes of heavy metal pollution in both Rivers. The presence and dispersion of the heavy metals along the flow lines were higher in the water samples for the Asuokofi than the Owerri River but the reverse was for the sediments (Table 2). It was observed that the higher the levels of the heavy metals in the water samples, the lower it is in the sediments and vice versa. However, the levels of some of the heavy metals (Lead) in the sediments were higher than those in the water column, this may be due to the ability of the metals to dissolve in the sediments and flow along the flow lines downstream. The Mercury levels in Asuokofi were higher than those of the Owerri River both in the water column and sediments. The levels in the sediment and water were higher; this may be due to the incessant usage of the $\mathrm{Hg}$ in amalgamating the gold ore in the Asuokofi River more than those in the Owerri River. The levels of the As were higher in Asuokofi water sample than that of the Owerri River but the levels were extremely higher in the sediments of the Owerri River than the Asuokofi River. This may be attributed to the higher occurrence of arsenopyrite in the Owerri river course than Asuokofi leading to higher arsenic in the Owerri River. The levels of cadmium metal in the Owerri River were higher than that of the Asuofi for both the water column and sediments.

Generally, the levels of metals in the sediments were above that of the water column (Table 2). This is because; most metals are insoluble in water but are easily bound to the sediments. Furthermore, the metals in the aquatic ecosystems are mainly deposited in sediment and sediment acts as a source and as a sink. As a consequence, benthic biota living in a metal-polluted environment can have a very high level of metals (note: Benthos organisms such as mussels are used in biomonitoring of heavy metal pollution in the marine environment). The presence of these contaminants in sediments may influence a high peril of human infection due to resuspension by natural turbulence or human activities. The levels of almost all the heavy metal pollutants under consideration in both River especially Asuokofi were well dispersed and well above the WHO guidelines (Table 2) and the control point levels along the flow lines. There was a gradual decrease in the levels of pollutants from the upstream to the downstream. There is the tendency of the levels of pollutants in the sediments to further dissolve in the water whenever there is a disturbance at the bed of the streams which may further increase the levels of the metal way above the World Health Organisation (WHO) standards thereby endangering the lives of the communities. Comparing this results with other similar studies conducted in Dunkwah-on-offin (Kpan et al., 2014) and Tarkwah (Boamponsem et al., 2010) in the Central and Western Regions respectively of Ghana, confirm that the activities of illegal mining contribute to heavy metal pollution in water 
and sediments. Their findings also confirm the decline of the heavy metal concentrations along the flow lines downstream.

From the maps shown in Fig. 2-4, most of the vegetation/farmlands and settlements are very close (about $20 \mathrm{~m}$ ) to these streams where the illegal mining is being carried out of which the communities rely heavily on irrigation and domestic uses. The high levels of the heavy metals in the sediments give rise for concern on the impact of food security in the area. There is the tendency for the crops grown within the mining enclave to bio accumulate some of the heavy metals and subsequently to be consumed by both man and animals. The Physicochemical parameters analysed for the two streams were; $\mathrm{pH}$, conductivity, TDS and Turbidity. The average Hvalue obtained was 6.3. Except for Turbidity, all the samples fell within the WHO range for potable water. The average turbidity was 4128 NTU which is far above, the limit 5NTU. The Electrical Conductivity (EC) for all samples fell within the permissible limit of $500 \mu \mathrm{S} / \mathrm{cm}$ set by WHO. TDS value was generally $107.23 \mathrm{mg} / \mathrm{L}$ which was within the WHO permissible limit. This showed that the two-stream water in the area was quite fresh in most locations.

\section{Conclusion}

The pollution of the Owerri and Asuokofi can be attributed to the activities of illegal mining within their enclave. The activities of illegal mining within the catchment could also be as a result of land use and land cover changes. The predominant pollutant within these rivers is mostly $\mathrm{Hg}, \mathrm{As}, \mathrm{Cd}$ and $\mathrm{Pb}$. The levels of these pollutants within the water substrate and sediments are above the WHO standards. Unfortunately, these pollutants are not localized but can disperse along the flow lines of the River. This further endangers the lives of the inhabitants both at the upstream and downstream. There is both a positive and negative correlation between the pollutants, indicating the predictability of one pollutant with levels of the other pollutant.

\section{Acknowledgment}

We acknowledge the immense contribution by the Water Resources Commission of Ghana and Ghana Environmental Protection Agency for making available to us all the necessary resources and permit rendered to us to carry out this very important research.

\section{Author's Contributions}

Samuel Wiafe: Conceptualized the research topic, formulated the objectives and methodology of the research and participated the data collection and analysis.

Richard Buamah: He carried out both the Laboratory and Field Investigation as well as the Data Curation of the research work.
Helen Essandoh: He carried out Laboratory work and also assisted in the writing of the manuscript.

\section{Ethics}

This manuscript has never been published in any journal or sent to any journal for consideration and publication. Strict scientific ethical standard were adhered to.

\section{References}

Amankwah, E. (2013). Impact of illegal mining on water resources for domestic and irrigation purposes. ARPN journal of Earth Sciences, 2(3), 117-121. https://pdf4pro.com/view/impact-of-illegal-miningon-water-arpn-145545.html

Ampomah, B. (2017). 60\% of Ghana's water bodies' polluted-Water Resources Commission. Executive Secretary of the Commission at a Workshop in Ho, Source: GNA. https://www.businesshumanrights.org/es/\%C3\%BAltimas-noticias/ghana60-of-water-bodies-polluted-due-to-illegal-miningand-other-activities-say-authorities/

Andres, L. A., Bhatt, S., Dasgupta, B., Echenique, J. A., Gething, P. W., Grabinsky Zabludovsky, J., \& Joseph, G. (2018). Geo-spatial modeling of access to water and sanitation in Nigeria. The World Bank. http://documents. worldbank.org/curated/en/6008515 19849935055/Geo-spatial-modeling-of-access-towater-and-sanitation-in-Nigeria

Atayi, J., Kabo-bah, A., \& Akpoti, K. (2016). The effects of large-scale mining on land use and land cover changes using remotely sensed data 1 . International Journal of Science and Nature, 7, 724-16. https://www.researchgate.net/publication/320627 7

Bansah, K. J., Yalley, A. B., \& Dumakor-Dupey, N. (2016). The hazardous nature of small scale underground mining in Ghana. Journal of Sustainable Mining, 15(1), 8-25. https://doi.org/10.1016/j.jsm.2016.04.004

Berihu, T., Girmay, G., Sebhatleab, M., Berhane, E., Zenebe, A., \& Sigua, G. C. (2017). Soil carbon and nitrogen losses following deforestation in Ethiopia. Agronomy for Sustainable Development, 37(1), 1-12. https://doi.org/10.1007/s13593-016-0408-4

Boadi, B., Wemegah, D. D., \& Preko, K. (2013). Geological and structural interpretation of the Konongo area of the Ashanti gold belt of Ghana from aeromagnetic and radiometric data. International Research Journal of Geology and Mining, 3(3), 124-135. http://www.interesjournals.org/IRJGM 
Boamponsem, L. K., Adam, J. I., Dampare, S. B., OwusuAnsah, E., \& Addae, G. (2010). Heavy metals level in streams of Tarkwa gold mining area of Ghana. Journal of Chemical and Pharmaceutical Research, 2(3), 504-527.

https://www.academia.edu/32849811/Heavy_metals _level_in_streams_of_Tarkwa_gold_mining_area_o f_Ghana

Duncan, A. E., de Vries, N., \& Nyarko, K. B. (2018). Assessment of heavy metal pollution in the sediments of the River Pra and its tributaries. Water, Air, \& Soil Pollution, 229(8), 1-10. https://doi.org/10.1007/s11270018-3899-6

Emmanuel, A. Y., Jerry, C. S., \& Dzigbodi, D. A. (2018). Review of environmental and health impacts of mining in Ghana. Journal of Health and Pollution, 8(17), 43-52. https://doi.org/10.5696/2156-9614-8.17.43.

Fiedler, H., Kallenborn, R., De Boer, J., \& Sydnes, L. K. (2019). The Stockholm Convention: A tool for the global regulation of persistent organic pollutants. Chemistry International, 41(2), 4-11. https://doi.org/10.1515/ci-2019-0202

García, O., Veiga, M. M., Cordy, P., Suescún, O. E., Molina, J. M., \& Roeser, M. (2015). Artisanal gold mining in Antioquia, Colombia: a successful case of mercury reduction. Journal of Cleaner Production, 90, 244-252. https://doi.org/10.1016/j.jclepro.2014.11.032

Ghana Statistical Service. (2012), 2000 Population and Housing Census, Mediaite Co. Ltd.

George, A. (2013). Heavy metal Concentration in the Owerri River at Konongo. MSc. Thesis. Kwame Nkrumah University of Science and Technology, Kumasi.

Hasan, M. K., Shahriar, A., \& Jim, K. U. (2019). Water pollution in Bangladesh and its impact on public health. Heliyon, 5(8), e02145. https://doi.org/10.1016/j.heliyon.2019.e02145

Inyinbor Adejumoke, A., Adebesin Babatunde, O., Oluyori Abimbola, P., Adelani Akande Tabitha, A., Dada Adewumi, O., \& Oreofe Toyin, A. (2018). Water pollution: effects, prevention and climatic impact. In: Glavan, M. (Ed.), Water Challenges of an Urbanizing World, (pp. 13-32), BoD - Books on Demand, ISBN-10: 9535138936.

Kooy, M., Walter, C. T., \& Prabaharyaka, I. (2018). Inclusive development of urban water services in Jakarta: The role of groundwater. Habitat International, 73, 109-118. https://doi.org/10.1016/j.habitatint.2016.10.006

Khatri, N., \& Tyagi, S. (2015). Influences of natural and anthropogenic factors on surface and groundwater quality in rural and urban areas. Frontiers in Life Science, 8(1), 23-39. https://doi.org/10.1080/21553769.2014.933716
Kpan, J. D., Opoku, B. K., \& Gloria, A. (2014). Heavy metal pollution in soil and water in some selected towns in Dunkwa-on-Offin District in the Central Region of Ghana as a result of small scale gold mining. Journal of Agricultural Chemistry and Environment, 3(02), 40. https://doi.org/10.4236/jacen.2014.32006

Kumar, A., \& Pandey, A. C. (2013). Evaluating Impact of coal mining activity on landuse/landcover using temporal satellite images in South Karanpura coalfields and environs, Jharkhand State, India. International Journal of Advanced Remote Sensing and GIS, 2(1), 183-197. http://technical.cloudjournals.com/index.php/IJARSG/article/view/Tec h-110

Levin, E. (2014). Global trends in artisanal and smallscale mining: What do these mean for Mongolia? www.estellelevin.com/global-trends-in-artisanaland-small-scalemining-what-do-these-mean-formongolia

Lodha, R. M., Purohit, K. J., \& Yadav, S. H. (2009). Environment and mining: A peep into deep. Aggrotech Pub., ISBN-13: 9788185680682.

Lu, J. L. (2012). Occupational health and safety in small scale mining: Focus on women workers in the Philippines. Journal of International Women's Studies, 13(3), 103-113. https://vc.bridgew.edu/jiws/vol13/iss3/7/

Nzunda, H. P. (2013). Impacts of mining activities on land cover and forest stock in Mbozi district, Mbeya region, Tanzania (Doctoral dissertation, Sokoine University of Agriculture). http://www.suaire.sua.ac.tz/handle/123456789/469

Persaud, A. W., Telmer, K. H., Costa, M., \& Moore, M. L. (2017). Artisanal and small-scale gold mining in Senegal: livelihoods, customary authority and formalization. Society \& Natural Resources, 30(8), 980-993.

https://doi.org/10.1080/08941920.2016.1273417

Shanbehzadeh, S., Vahid Dastjerdi, M., Hassanzadeh, A., \& Kiyanizadeh, T. (2014). Heavy metals in water and sediment: a case study of Tembi River. Journal of environmental and public health, 2014. https://doi.org/10.1155/2014/858720

Seccatore, J., Veiga, M., Origliasso, C., Marin, T., \& De Tomi, G. (2014). An estimation of the artisanal smallscale production of gold in the world. Science of the Total Environment, 496, 662-667. https://doi.org/10.1016/j.scitotenv.2014.05.003 